\title{
Theology without Anathemas
}

\author{
Steven Nemes \\ North Phoenix Preparatory Academy
}

\begin{abstract}
The object of the present essay is to establish the possibility of "theology without anathemas." First, an argument is given for the conclusion that infallible knowledge in matters of theology is not now possible. Both the Protestant doctrine of claritas scripturae and the Roman Catholic understanding of the Magisterium of the Church are rejected. Then, an alternative, "fallibilist" ecclesiology is proposed, according to which (knowingly) to belong to the Church is a matter of (understanding oneself as) having been claimed by Christ as His own. When combined with a universal doctrine of election and a highly objective and actualized doctrine of the Atonement, such a conception of the Church makes it possible to understand theology as a collaborative and cooperative effort on the part of all to understand better this Christ to whom they all always already belong.
\end{abstract}

\section{Introductory Summary of the Argument}

Christian theology in some quarters admits the possibility of at least some infallible theological knowledge. This admission takes different forms in different contexts. In the Protestant tradition, the doctrine of claritas scripturae (perspicuity of Scripture) maintains that the Holy Spirit grants the regenerate reader an infallible grasp of the essential truths of the Gospel in the words of the Bible. In Roman Catholicism, by way of contrast, infallibility is granted to the Magisterium of the Church in certain conditions: first, when all bishops in communion with one another and with the Pope speak in perfect unanimity across all times and places on some matter they take to be essential to the faith; second, when it makes pronouncements collegially in an ecumenical council; and third, when the Bishop of Rome speaks ex cathedra seeking to define some matter pertaining to faith or morals. In either case, however, the possibility is admitted in principle that the Holy Spirit can secure infallible knowledge of some theological matters to at least some Christians.

It would seem that the admission of the possibility of infallibility in theology goes hand in hand with what might be called a "doctrinal" conception of the Church, according to which membership in the Body of Christ entails belief in or at least assent to certain well-defined theological claims. If the essential truths of the Gospel are clear to all enlightened readers of Scripture, then it would seem to follow that all those who have the Holy Spirit should in principle agree on whatever doctrinal formulations are essential to the faith. If one and the same thing is clear to two different persons, then they should agree about how to talk about it. Likewise, if it is in the authority of the

Journal of Analytic Theology, Vol. 9, Summer 2021

$10.12978 /$ jat.2021-9.181913130418

(C) 2021 Steven Nemes • (C) 2021 Journal of Analytic Theology 
Magisterium of the Church to teach infallibly on some matters, one cannot remain in communion with this Church so long as one willingly dissents from these. In either case, then, there appears to be a connection between the acceptance of the possibility of infallibility in theology and the "doctrinal" conception of the Church.

On the other hand, it can be seen that the denial of the possibility of infallibility in theology motivates the rejection of the "doctrinal" conception of the Church, lest a person find him- or herself in constant salvation-anxiety. This calls for a reconceptualization of the Church in appreciation of the fact that theological knowledge is only ever fallible and possibly mistaken. The goal of the present essay is to argue for the fallibility of theological knowledge and correspondingly to develop a "fallibilist" alternative to the "doctrinal" conception of the Church. This "fallibilist" conception will revolve around a revisionist interpretation of two important principles of Reformation theology: ecclesiological solus Christus, which holds that the objective being of the Church consists in its being claimed by Christ as His own; and ecclesiological sola fide, which maintains that to be a Christian is have an abiding conception of oneself as belonging belong "body and soul, in life and in death" to Christ the Savior. ${ }^{1}$

The most significant consequence of the "fallibilist" conception of the Church is that, if coupled with certain understandings of election and the doctrine of the Atonement, it makes "theology without anathemas" possible. Once all the arguments are presented, the present essay will conclude with a consideration of this point.

\section{Infallible Theological Knowledge?}

The following argument can be given against the claim that infallible theological knowledge is presently possible for human beings:

(1) Knowledge is the presence-to-consciousness of the known thing in evident conformity with the judgment one makes about it.

(2) The things of Christian doctrine cannot now be made infallibly present to consciousness.

Therefore,

(3) The things of Christian doctrine cannot now be known infallibly.

It would be well to go over these premises in turn.

\footnotetext{
1 The goal of this essay is not accurately to represent the views of any particular Reformed theologian, but to make a constructive proposal of its own, however revisionist its use of the principles of solus Christus and sola fide.
} 


\section{That knowledge is presence-to-consciousness}

For the purposes of this essay, to know is for the thing one knows to be itself given to one's consciousness in conformity with the judgment one makes about it. ${ }^{2}$ This understanding of knowledge as the presence-to-consciousness of the thing known has been especially developed by the phenomenological tradition of philosophy under the name of "evidence." It is important to recognize that, in this context, "evidence" is a property of things and not a kind of thing on its own. "Evidence" in the phenomenological sense does not refer to reasons for believing a proposition or anything of the sort. Rather, phenomenology understands "evidence" as a cognitive accomplishment in which a thing about which one forms some judgment is given in intuition, i.e. in propria persona in some form of consciousness, in such a way as to conform to a judgment one has made about it (Heidegger 1985, 47, 49-50; Sokolowski 2000, ch. 11; Zahavi 2003, 31ff.). For example, suppose Oliver judges that a cat is white. If Oliver is to know that the cat is white, this cat must itself be given to his consciousness in such a way as to conform to the judgment he makes about it - i.e., he must see it to be white. Once he does, he achieves "evidence." And in general, phenomenology conceives of all knowledge as at base a form of "seeing" (Henry 2012a, 10), though obviously this does not mean only seeing-with-the-eyes. One surely can also "see" that $2+2=4$ or that one cannot know what is not true (cf. Henry $2012 \mathrm{~b}, 70-71)$. In all such cases, one "sees" as a result of the presence to one's consciousness of some thing or other. In an act of consciousness, one is directly presented with an object which conforms to the judgment one makes about it. This reveals that there are in fact two aspects of evidence (Husserl 1969, 127; 1973, 19f.). On the one hand, there is what might be called judgment-evidence, viz. the evident correspondence of the judgment made about some object with that object itself. On the other hand, there is what might be called object-evidence, which is the clarity or evidence with which the object of the judgment is given in some form of experience or other. It is clear that one cannot see that a judgment corresponds to its object unless this object is itself clearly given, so that object-evidence is the presupposition of judgment-evidence. One could not see the evidence of one's judgment that the cat is white if this cat were not itself clearly visible. This is the sense in which the knowledge of a thing is a matter of the "evident" presence-to-consciousness of the thing in question.

This may not be the conception of knowledge with which many analytic theologians are familiar. The analytic philosophical tradition tends to characterize knowledge fundamentally in terms of a relation between a believing agent and a true proposition (e.g., knowledge as warranted true belief). But this is not as far removed from the phenomenological conception as might initially seem to be the case. Phenomenology emphasizes that knowledge is a kind of "spiritual intimacy" with the known object (Hildebrand 1973, ch. 1). It is an experienced connection between the mind and the known thing (Hopp 2020, 214). And because phenomenologists all subscribe to a form of direct realism, rather than thinking that the mind's access to

\footnotetext{
2 If one simply refuses to accept this premise, the argument of this paper will not seem very convincing.
} There is no space here to defend it at great length, but see Hopp (2020, ch. 9). 
the world is necessarily mediated through representations or "ideas" (Sokolowski 2000, 9ff.; 2008, ch. 10; Zahavi 2016, 20), they say that knowledge is first and foremost of things in the world - e.g., one knows the cat as white. Analytic philosophers, on the other hand, perhaps influenced by Frege's (1948) distinction between sense and reference, tend to think of the relation between the knowing mind and the world as mediated through propositions. One does not simply know things directly, but rather believes a proposition in a knowledge-securing way. But perhaps the analytic philosopher could still grant that what one knows in the strict sense is the proposition, which is present to the consciousness which believes in it-it becomes present once one thinks about it for a moment-and thus is in a direct relation with the mind. And the analytic epistemologist could also grant that one knows a proposition when one sees it to be true, e.g. by seeing it in relation to various forms of "evidence" one has at one's disposal or else by directly sensing its truth. Thus, in spite of differences in terminology and metaphysics, the analytic epistemologist could appear implicitly to grant the phenomenological conception of knowledge as consisting in the presence-to-consciousness of the known object.

\section{That the things of Christian doctrine cannot now be made infallibly present}

The things of Christian doctrine cannot now be made infallibly present to consciousness. What are the "things" of Christian doctrine? Veli-Matti Kärkkäinen (2013, ch. 1), following Wolfhart Pannenberg $(1991,5)$ and Thomas Aquinas (ST I.2 a 2; cf. 1.1 a 7 ad 1, as cited in Pannenberg 1991, 5), says that Christian theology is concerned with God and with all things insofar as they are related to God. Some of the things Christian theology affirms are not unique, nor even specifically theological, and can in principle be granted even by a non-Christian: for example, that God exists, or that Jesus of Nazareth existed during the beginning of the first century of the common era, or that David was king of the Kingdom of Israel some long time ago. But Christianity also distinguishes itself from history or even natural theology in that it makes further claims about the meanings of historical and natural realities. Jesus not only lived two thousand years ago, but He was also the Son of God. His death was not merely a crucifixion but also an atonement for the forgiveness of sins of the whole world. His Resurrection was not merely the surprising revivification of a dead body at some point in history but a fundamental transformation of His bodily life and the "inauguration" of a new creation and a restoration of an original dominion of the human being over the world (cf. Middleton 2014). In a strict sense, then, it would seem appropriate to say that the "things" of Christian theology would consist in these distinctly theological interpretations of the theological significance of history and nature. Christianity is distinguished from mere history or natural theology because of the "something more" that it says about history and nature. The question must now be asked whether the "something more" that Christianity says can be made infallibly present to consciousness so that it might be known infallibly.

It would seem that it cannot. The reason why it cannot be made infallibly present to consciousness is because, in order to access the "something more" that Christianity says, in order to "see" it, one must make a hermeneutical decision about 
how to understand things. And because one must make a decision, it follows that the success of one's decision is fallible, since one's choice could always be mistaken. This is a general fact about interpretation as such. Interpretation begins with a "given" which is not yet understood. One chooses to interpret this given in a certain way in the hope that this interpretation will shed light on it (Marion 2013, 41-43; cf. Caputo 2018). The way that "light is shed" on the interpreted object is that later experiences serve to confirm what one earlier judged about it. What was previously unintelligible becomes intelligible. But where one has to make a choice, one can also make a mistake. One might choose to interpret something in one way and later find that the interpretation was mistaken. For example, one might judge that someone seen from far away is a friend when from up close one discovers that it is a stranger. "Who is that? Could it be Oliver? ... Ah, my mistake, I thought you were someone else." One can imagine a slightly more complicated example. Suppose that Diana has been acting strangely lately. Her husband, Michael, wants to know why. The reason why is the truth he wishes to access. In order to reach it, he must make a decision about how to interpret her behavior. Suppose he suspects that she might be upset at him. This interpretation helps to make sense of his experiences: it explains why Diana has been very reserved, tentative about committing to weekend plans, unwilling to go into detail about what she has been thinking or feeling lately, and so on. After the choice to interpret things this way, what was previously unclear now becomes intelligible. But later it turns out he was mistaken. She was in fact planning a surprise party for him. Nota bene: the interpretation he gave did provide light; it made sense of the things she was doing and the way she was acting. But it was later revealed to be mistaken. It was a false light. This example illustrates what is meant by saying that the goal of the hermeneutical decision is to make something present, to shed light on a given phenomenon, yet in such a way that this light can be deceptive owing to the inevitable fallibility of the decision. Michael's wife's actions did not speak for themselves. He had to make a choice about how to think about them. Once he had made a choice, the situation was made intelligible. But the light shed was a false one. And indeed, the possibility of error was there from the beginning precisely because a choice had to be made. Nothing is accessed infallibly which must be accessed by an interpretive choice, since there is always the possibility of choosing wrongly. If it could be accessed infallibly, there would be no need for choice. So also, because the "things" of Christian doctrine, the "something more" that Christianity teaches, are only made present by a choice, for that reason they cannot be made infallibly present to consciousness.

It would be well to consider a few examples of how the "things" taught by Christianity are only accessible on the basis of a hermeneutical decision. In the first place, Christianity is commonly thought of as a "revealed religion" and not as natural theology. This means that the truth of the statements it makes is not accessible "naturally," on the basis of the senses and reason with which the human being is naturally endowed. Rather, what it teaches is "supernatural." And because it is supernatural, there is no "way up" from the natural to it. The only way to reach the "supernatural" is to attribute to the natural more than what is immediately perceptible. In this sense, consider what T.F. Torrance says about the fact of Christ, the God-Man: 
We cannot compare the fact of Christ with other facts, nor can we deduce the fact of Christ from our knowledge of other facts. The fact of Christ comes breaking into the continuity of our human knowledge as an utterly distinctive and unique fact, which we cannot understand in terms of other facts, which we cannot reduce to what we already know. It is a new and unique fact without analogy anywhere in human experience (Torrance 2008, 1).

If the fact of Christ, the God-Man, "comes breaking into the continuity of our human knowledge as an utterly distinct and unique fact," then it follows that it cannot be known naturally. Christ's divinity is not something that can be seen in the way that one sees His hair or His height or weight. One cannot deduce it from whatever one already knows. And yet Christ appears in the world as a human being. To say that $\mathrm{He}$ is a human being is not very controversial. It is enough to see that He has a human body and that He does human things. In this sense, one has as much reason to think that He is human as one has to think that anyone else is human. To say that He is more than a human being, that He is also God, is to ascribe to Him something that is not immediately evident. That it is not immediately evident explains why some of those who saw Him did not believe that He was the Son of God at all, although He was as visible to them as to His own disciples (Matt. 16:1-4, 13ff.). And in order to make that further ascription of meaning, to say that He is more than just a man, it is necessary to interpret Him, to make a decision about how to understand Him. But where a choice is to be made, the options are typically multiple. One could say that Christ is God, but one could also say that He is a magician, or a charlatan, or a very skilled trickster, or whatever (cf. Matt. 12:24). Thus, one does not have immediate "access" to the supernatural aspect of Jesus. One must ascribe that meaning to Him in order to make it present in some way. In other words, one must choose to believe that He is the Son of God, rather than a magician or a trickster, in the hope that this belief will be confirmed in later experience. And because a choice must be made, it is also possible to make the wrong choice. Thus, the distinctly supernatural or theological Christian proposal in the teaching about Jesus is not capable of being made infallibly present to consciousness.

The things of Christian theology cannot be made infallibly present to consciousness in the sense that they are theological. But it is also true that Christianity is concerned with the past and the future. On the one hand, Christianity makes several affirmations of an "aorist" nature about things that have happened. Thus, Jude enjoins his readers to "contend for the faith that was once for all entrusted to the saints" (Jude 3). And Paul speaks of the Gospel message in aorist terms: "Christ died (apethanen) for our sins" (1. Cor. 15:3). Peter too: "Christ also suffered for sins once for all (hapax peri harmatiôn epathen)" (1 Pet. 3:18). Aside from the fact that Christ's death is interpreted as being "for sins," and thus a theological meaning is given to an historical event, it is also plain that a claim is being made about the past. And every claim about the past is necessarily a fallible one insofar as the past is not immediately present for one to describe. On the other hand, Christianity makes several assertions about the future; indeed, it proposes a way of understanding present experiences in light of a promised future. Thus Paul: "I consider that the sufferings of this present time are not 
worth comparing with the glory that will be revealed to us... We know that all things work together for good for those who love God, who are called according to His purpose" (Rom. 8:18, 28). Whereas tremendous suffering can rob a person of the hope that his or her life will be a good one in the end, Christianity teaches that one ought to think of the things one suffers not as utterly damaging, but rather as contributing in some way to one's ultimate salvation and deliverance. But once more, it is clear that an interpretation is being given to things that are present which goes beyond the mere "data" or "givens" of experience. Suppose that one suffers harm. One does not immediately see that this will be for the good, but rather must choose to take it that way in the hope that this interpretation will later be confirmed. And because one must make a choice about how to interpret it, it is also possible for the wrong interpretation to be given. Perhaps it will not be for the ultimate good. Perhaps one will die and be annihilated and that is all. Thus, insofar as Christianity makes affirmations about things past and future, it also makes claims about realities which cannot be made infallibly present. That is to say, it posits realities which cannot be accessed apart from a choice to interpret things in a certain way.

There is one more aspect to be noted. Christ challenged His contemporaries to make a decision about how to interpret Him (Matt. 16:13; cf. Gschwandtner 2010, 154). Some of them responded by believing that He was the Christ, the Holy One of God, whereas others believed that He had a demon and that He worked miracles by the power of Beelzebul (Matt. 12:24). But at least these contemporaries had Christ before them and were able to see what He did and hear what He said. For those living in the twenty-first century, this is no longer possible. It is no longer just a matter of trusting what Christ says about Himself, but also trusting what others say about Him. There is no access to Christ apart from the testimony of His followers (Nemes 2017). And it is clear that there is a hermeneutical decision to be made here as well. One might think that the New Testament accurately reports the substance of Christ's selfunderstanding and still reject the notion that He is the Son of God. But one might also judge, as some do, that the New Testament is not a reliable source regarding the person of Jesus of Nazareth at all. One might even go so far as to say that Jesus never existed. Even if one does not consider this latter option plausible at all, it is nevertheless a possible hermeneutical choice, however shortsighted or oversuspicious or unreasonable. In this way, the things of Christian doctrine are even more hermeneutically distant than one might have suspected. It is not merely a matter of believing what Jesus says about Himself. It is also a matter of believing that others have faithfully transmitted His self-understanding in what they have written.

In these ways, then, it becomes clear that the "things" of Christian doctrine cannot be present to conscious in an infallible way, since they cannot be accessed unless one makes a number of hermeneutical decisions about what to believe and how to understand things. And because for every hermeneutical decision, there is an opposite decision that could have been made, - for every decision to trust, there was also the possibility of distrusting, - it follows that it is always possible for one to have erred. Therefore, the presence-to-consciousness secured on the basis of the hermeneutical decision is a fallible one. 


\section{The impossibility of infallible theological knowledge}

The conclusion of the argument follows as a matter of logical consequence. Knowledge presupposes presence-to-consciousness. The "things" of Christian theology cannot now be made infallibly present to consciousness. They are only made present on the basis of a hermeneutical decision for which there existed alternatives and which thus might have been mistaken. As a result, it follows that the "things" of Christian theology cannot now be known infallibly. They are not infallible knowledge but rather items of faith.

\section{Possible Objections and Responses}

It would be well at this point to consider a few possible objections to this argument, as well as some responses to those objections.

The first objection says: The hermeneutical decision to interpret something a certain way - which could also be called faith - does not compensate for the lack of visibility of something, but rather makes it possible to see something which otherwise could not be seen. The believed-in thing was always there, but it was not visible until it was believed in. This is the opinion of Jean-Luc Marion (2017). He gives the example of the disciples from Emmaus. Christ was with them all the time, and yet until $\mathrm{He}$ taught them from the Scriptures and broke the bread before them, they could not recognize Him for who He was. In response: It is true that sometimes faith makes it possible to see something that cannot be seen without it. Nothing excludes the possibility of realities that must first be believed in before being seen. For example, one could never discover whether another person is trustworthy except by first trusting the other. There is always the possibility of a suspicious interpretation of what another does or says. The only way for the trustworthiness of the other to be seen is for the suspicion to be laid to the side and the other trusted in. But it is also clear that the light which faith provides can sometimes be a false one. One can trust a person who is in fact not trustworthy. One can begin to believe something and find that it makes sense of a lot of things only later to discover that in fact it was false. And even Marion himself takes for granted the truth and accuracy of Luke's account of the encounter had by the disciples on the way to Emmaus in order to make his point. It therefore seems that faith remains a "conviction of things not seen" (Heb. 11:1). It can make visible, but only fallibly so.

The second objection says: This argument applies to all forms of knowledge whatsoever and therefore is uninteresting. In response: At first glance, this objection would seem to grant the point being made. But in fact, not all knowledge is fallible. At this point, one could invoke the distinction between two forms of knowing highlighted by the phenomenologist Michel Henry (2002; 2012b). On the one hand, there is the kind of knowing which involves a consciousness being intentionally related to a given object, as when one knows a thing or a state of affairs or a proposition or whatever. In such cases, the fallibility of knowledge arises because the givenness of the object itself is impossible to secure infallibly. The "firmness" with 
which one knows that the cat is white depends on the degree to which one can make the cat present. But on the other hand, there is a kind of knowing which does not involve an intentional relation to an object appearing "outside" oneself, in "the world." This latter kind of knowing is called life. For Henry, life in the true phenomenological sense is not a biological phenomenon, nor does it have to do at all with anything that appears in the "outside" (2002, 34ff.). Rather, life is self-affection: feeling and experiencing oneself in such a way that there is no difference between what feels and what is felt $(2012 a, 6)$. Henry (2008) argues that the true meaning of the Cartesian cogito ergo sum is the infallibility of life understood as feeling oneself to be affected. It would therefore seem that not all knowledge is fallible. The phenomenon of life, such as Henry describes it, might be understood as a kind of infallible presence-toconsciousness because what is present is the same as that to which it is present.

The third objection says: Perhaps we can know things apart from their presence-to-consciousness; perhaps we know them because we can simply see (by the help of the Holy Spirit) that the propositions describing them are true, through a form of "propositional perception." This is more or less the Barth-Plantinga synthesis which was developed by Kevin Diller (2014). In response: The argument has already been given elsewhere (Nemes 2019) that it is not in fact possible to see the truth of a proposition in the absence-to-consciousness of its referent, the state of affairs which the proposition is describing. The truth of a proposition is a relation which obtains between it and its referent (i.e. what it is about). But one cannot see a relation without also seeing both of the relata. For example, one cannot see that one cat is bigger than the other if only one is visible. In the same way, one cannot see that a proposition is true if the referent of the proposition is not also given. Thus, one cannot see that $x>$ 100 unless the value of $x$ is given. And since the mode of givenness of the referent of the proposition will clearly affect the knowledge one has of it, one cannot know a proposition infallibly unless the referent of the proposition itself can be made infallibly present.

The fourth objection says: The Holy Spirit could in some way compensate for the fallibility of human knowing so as to secure infallible theological knowledge. This is the most important objection to the present argument. It would be worth addressing in a separate section.

\section{Theological Infallibility and the Holy Spirit}

Suppose someone were to suggest that Holy Spirit could grant human beings infallible knowledge of the things of Christian doctrine. There would seem to be principally two ways in which this proposal could be fleshed out. First, one could opt for the Protestant notion of claritas scripturae (perspicuity of Scripture), which says that, for all those who are truly enlightened by the Holy Spirit, the essential meaning of the Gospel in the words of Scripture is impossible to miss (Vanhoozer 2016, 112-113; cf. Callahan 1996; 2001; Thompson 2006). Second, one could opt for the Roman Catholic doctrine of the Magisterium of the Church, according to which the Church makes infallible doctrinal pronouncements under certain conditions: the universal ordinary 
magisterium, when all bishops everywhere and all times, in communion with one another and with the Bishop of Rome, agree in some teaching as definitively to be held; and the extraordinary magisterium, when either an ecumenical council is convened with the ratification of the Bishop of Rome, or else when the Bishop of Rome speaks ex cathedra with the intention of defining some matter pertaining to faith or morals (Lumen Gentium 25; Sullivan 1983; Dulles 2017). But these proposals amount, in the end, to the same thing. In both cases, a privileged class of scriptural readers or theologians is established through the special work of the Holy Spirit. In the Protestant case, it is all the true faithful, whereas in the Roman Catholic case, it is specifically the Magisterium of the Church, whether as a whole or in the Bishop of Rome in particular, insofar as this has been specially charged with the propagation of doctrine (Dei Verbum 8, 10). In both cases, the question raised is the same: What justifies one in claiming that one has received this grace of infallibility?

Begin with the case of claritas scripturae (cf. Nemes 2019). Suppose that Oliver takes himself to be a Christian and to understand clearly some teaching of Scripture which he considers to be essential to the Gospel. He also maintains the doctrine of the perspicuity of Scripture, according to which all those who are truly enlightened by the Holy Spirit are granted an infallible access to the essential saving truths of the Gospel in Scripture. This commits him to the view that those who persistently disagree with him on the matter in question do not have the Holy Spirit. But this is a purely formal definition that seems to hang in midair. It says: all $x$ s are $F$. The material question arises: why think Oliver is an $x$ and therefore $F$ ? In other words, how does Oliver know that he is a Christian enlightened by the Holy Spirit, and that what he takes to be an essential matter is in fact one? In virtue of what does he claim to be a beneficiary of the supposed infallibilizing operation of the Holy Spirit? He cannot simply say that he believes what Scripture teaches about essential matters, because the very question at hand is whether he does in fact have infallible access to what Scripture teaches as essential. Nor can he simply point to his own conviction of the truth of what he believes, since there can be others who feel equally convinced that he is wrong. In any case the feeling is irrelevant, since one can in principle be strongly convinced about a falsehood (Zahavi 2003, 32). Neither can Oliver appeal to a notion of "propositional perception," as if he could simply see that some things are true, since it was already shown above that it is impossible to perceive the truth of a proposition in the absence of its referent. The thing about which he has a belief is not present; at best, what he has before him is a text which he interprets as teaching it. But how can he be certain that his interpretation is correct? Nor could Oliver point to some moral or spiritual qualities on his own part as evidencing the operation of the Holy Spirit in him: perhaps there are none, or perhaps there are others who are more impressive in this respect and yet feel differently. There would therefore seem to be nothing to which Oliver could point in order to justify his conviction that the Holy Spirit has graciously granted him infallible access to some essential truth. But if he grants all this and still insists on his claim to infallibility, then what else can be said except that he is sectarian? He cannot even justify to himself his own conviction that he is a Christian, and yet he excludes others from the fold.

Something similar occurs also in the case of the Roman Catholic doctrine of the Magisterium. Roman Catholic theologians can generally give two kinds of arguments 
in favor of the doctrine of the infallible Magisterium, the arguments being mutually reinforcing. On the one hand, there is a kind of a priori argument which suggests that apart from the existence of an infallible Magisterium, saving revelation could not be adequately secured for all subsequent generations (Dulles 2017, 4-6; Ratzinger 1995, $62,54)$. On the other hand, the notion of the successio apostolica naturally develops into the notion of an infallible Magisterium, because the bishops, as successors of the apostles, were considered to possess the "sure gift of truth" (charisma veritatis certum; Irenaeus, Adv. Haer. 4:25:2, PG 7: 1053-54, cited in Dulles 2017, 22). Thus, the a priori foundationalist argument for the necessity of a magisterium is strengthened and confirmed by the historical development of a Magisterium on the basis of the notion of apostolic succession, and vice versa.

But one gets the impression that the Magisterium attempts to define itself into existence by means of this double argument: an historical development is taken as the confirmation of an a priori truth. In virtue of what? How does one connect the concrete and historical to the abstract and formal? The answer is obvious: because of the apostolic succession. There are some statements of episcopal authority in the earliest generations of Christianity that are quite impressive. For example, Ignatius says that "the bishops appointed throughout the world are in the mind of Christ" so that it is "proper for you to run together in harmony with the mind of the bishop... For your council of presbyters, which is worthy of its name and worthy of God, is attuned to the bishops as strings to a lyre" (Eph. 3:2-4:1). But it was also possible for a bishop participating in the apostolic succession to teach falsehood, such as Paul of Samosata in the third century (Dulles 2017, 23). What then has become of the "sure gift of truth"? The situation in fact leaves open two hermeneutic possibilities in response. On the one hand, one can maintain episcopal infallibility while limiting its efficacy to specific conditions. On the other hand, one can say that the guarantee of the truth of the teachings of the bishop only extends as far as their own evident conformity to some other intrinsically authoritative source (such as Scripture, the testimony of the apostles), it always remaining possible that the bishop can overstep the bounds of his authority by speaking on his own, without Scriptural support. On this view, the statements of episcopal authority in Ignatius and others could be true if taken materially, as referring to particular bishops whose teaching was agreeable to Scripture, and not formally, to the position of the bishop as such. Roman Catholic dogma takes the first path, but there is seemingly nothing preventing one from taking the second, as in Protestantism.

But suppose that one were to insist that the a priori argument for the infallibility of the Magisterium makes the first option more credible. In fact, the $a$ priori argument is logically invalid. Formally speaking, there is no need of an infallible Magisterium for the preservation of the saving truth from generation to generation. God could make use whatever means He has available, if He so wishes, and He could secure that there is always an available means, even if there is not always the same one. The infallibility of God thus does not necessarily translate into the permanence or infallibility of any particular tool He uses. The infallibility of the transmission of the saving truth does not require a unique infallible method. Moreover, this argument would once more amount to sectarianism. The argument amounts to the following claim: "If we, the Magisterium, were not infallible, then these saving truths, which we 
know to be essential to the Gospel, would be lost, or at least would not be reliably available." But the response is an easy one: "Perhaps you are mistaken about what is essential to the Gospel, in which case you are not as essential as you take yourself to be!" In other words, the rejection of the infallibility of the Magisterium also makes possible the rejection, at least in part, of the total theological "complex" which it promotes.

In this respect, one might also consider the argument of Francis A. Sullivan (1983, 6ff.): Christ promises the indefectibility of the Church, which means also its indefectibility in the faith; if the Church is indefectible in the faith, then the Church cannot have obligated its members to confess a falsehood; but the Church historically came to obligate its members to accept the infallibility of the Magisterium; therefore, the Magisterium is infallible. As he says, "the indefectibility of the Church in the truth requires that its normative confession of faith be expressed in propositions which, for all their inevitable limitations, are still true" (16). But this argument too is logically invalid. It is possible that the (Magisterium of the) Church has obligated its members to believe a falsehood and yet this falsehood has not affected its simultaneous preservation in and propagation of the saving truth. The Church can have continued to teach the saving truth while at the same time teaching something false, yet ultimately harmless.

Thus, whether one opts for the claritas scripturae or the infallibility of the Magisterium, there would seem to be a problem of justifying the claim that one benefits from the infallibilizing operation of the Holy Spirit. The proponent of the perspicuity of Scripture has no clear basis for judging himself or herself to have received the enlightenment of the Holy Spirit rather than another with whom he or she disagrees. The Roman Catholic doctrine of the Magisterium, on the other hand, runs into the problem of being an unnecessary doctrinal development. The a priori arguments for the necessity of an infallible Magisterium are logically invalid, and the historical argument from the development of the successio apostolica is an unnecessary one, since the reality of episcopal error undermines the claim to possess the "sure gift of truth."

But this discussion raises still more questions. If infallibility is not possible in theology, then on what basis is theology possible? Where does it begin? How are differences settled? How can dangerous error be excluded? Where are the boundaries of the Church? How can the truth save if it is mixed with error and falsehood? These questions will be addressed in the following section of the paper.

\section{Fallibilist Ecclesiology}

The notion of theological infallibility is closely connected with what might be called a "doctrinal" conception of the Church. According to this view, belonging to the Church, in the normal case, is at least in part a matter of assenting to certain precise and welldefined doctrinal formulae. But it would make little sense to accept such a conception of things if one did not also grant the possibility of infallible theological knowledge, since otherwise one would know whether one is oneself in the Church! Thus, Francis 
Sullivan emphasizes that the "very being of the Church is expressed by the term congregatio fidelium: community or congregation of believers" $(1983,6)$. The person who willingly and knowingly dissents from these doctrines for that reason shows himself or herself not to belong to the Church. The doctrinal conception of the Church thus goes hand in hand with the notion of theological infallibility.

If there is no infallibility in theology, then the "doctrinal" conception of the Church must be rejected. But it is not enough merely to reject it; something new must be put in its place. This will be called "fallibilist ecclesiology." It is founded on a (quite likely revisionist) interpretation of two Reformation principles: solus Christus and sola fide. This understanding of the Church, coupled together with a specific understanding of the doctrine of the Atonement, make possible a new approach to theology "without anathemas." In short, the proposal is as follows: the objective being of the Church consists in the fact that Christ claims some number of persons as His own; the subjective fulfillment of this in the life of a Christian consists in an abiding preoccupation with the person of Jesus as Savior, to whom one considers oneself to belong. This is what makes the Church and the Christian.

\section{Ecclesiological solus Christus}

According to ecclesiological solus Christus, the objective being of the Church consists in the fact that Christ claims some number of persons as His own. Because He claims them, they are therefore His own people (cf. 1 Pet. 2:10). He died for them in order to bring them to God and to give them eternal life (cf. 1 Pet. 3:18). This means that His attitude towards these persons is one of pure salvific intent. John says that Jesus Christ is "the atoning sacrifice for our sins" (1 John 2:2). Not Christ's death, not some moment in His life, but Christ Himself-the person-is the atoning sacrifice (cf. Purves 2015, 145). This would seem to make all of Christ's life and being to consist in the pursuit of the atonement of sins and the reconciliation of human beings with God. Thus Joseph Ratzinger: "Christ inflicts pure perdition on no one. In himself he is sheer salvation" (Ratzinger 1988, 205). In this sense, one could say that the objective being of the Church is grounded in the fact that it is chosen by Christ.

If election is the ground of the Church, then who is elect? Strictly speaking, the proponent of a fallibilist ecclesiology can leave this an open question. Perhaps it is a (vast) majority of all people, perhaps it is a (vast) minority, or perhaps it is exactly half. Fallibilist ecclesiology does not demand a particular answer to this question. But the preferred answer to be proposed here is: everyone. Everyone is the Church insofar as Christ claims all as His own. Thus, John teaches that Christ is the atoning sacrifice "not for [our sins] only, but for the sins of the whole world" (1 John 2:2). And the First Epistle to the Timothy teaches that Christ is the "one mediator between God and humankind ... who gave Himself as a ransom for all" (1 Tim. 2:5-6). Passages such as these can be understood as suggesting that Christ claims everyone for Himself and has "purchased" them through the sacrifice of the Cross (1 Pet. 3:18-19). Thus, although the proponent of fallibilist ecclesiology has options with respect to the "scope" of divine election, the preferred interpretation of the present work is that all 
people are elect. As will be seen later, this understanding helps resolve certain problems in the matter of "assurance of salvation."

Thus, according to ecclesiological solus Christus, the being of the Church has nothing to do with it itself. The Church is the Church simply because Christ claims it as His own, not because it is itself a certain way, believes certain things, or has various qualities. And although the proponent of a fallibilist ecclesiology can leave this question open, it is to be suggested here that Christ claims everyone as His own, so that, in an objective sense, everyone is the Church. The Gospel is how they come to know this fact about themselves.

\section{Ecclesiological sola fide}

If the objective being of the Church is the fact that Christ claims some number of persons as His own, then the subjective fulfillment of this in the life of a Christian consists in an abiding preoccupation with the person of Jesus as Savior, to whom one considers oneself to belong. This is what makes one a Christian. The point was beautifully summarized in the words of the Heidelberg Catechism:

Q1: What is your only comfort in life and in death?

A: That I am not my own, but belong - body and soul, in life and in death - to my faithful Savior, Jesus Christ. He has fully paid for all my sins with his precious blood, and has set me free from the tyranny of the devil. He also watches over me in such a way that not a hair can fall from my head without the will of my Father in heaven; in fact, all this must work together for my salvation. Because I belong to him, Christ, by his Holy Spirit, assures me of eternal life and makes me wholeheartedly willing and ready from now on to live for him (cited in Bierma 2016, 13).

It is thus important to understand the "indicative" nature of Christian faith. It consists in the belief that one has been saved by Christ and that one does belong to Him. In other words, a person is not yet a Christian who only thinks of Christ as "possibly" or "potentially" one's savior. This does not mean that a Christian cannot go through periods of doubt or even tremendous conflicts of conscience in which he or she despairs of being the object of Christ's love. But it is also clear that one could not remain in that state forever: either one abandons the faith altogether, or else takes it up anew. Thus, what John Calvin says seems right: "[W]e shall possess a right definition of faith if we call it a firm and certain knowledge of God's benevolence toward us, founded upon the truth of the freely given promise in Christ, both revealed to our minds and sealed upon our hearts through the Holy Spirit" (Institutes of the Christian Religion III, 2, 7, in Calvin 2006, 511).

Ecclesiological sola fide thus does not propose an understanding of faith that is absent of any doctrinal content whatsoever. It says that being a Christian is a matter of understanding oneself to belong "body and soul, in life and in death" to Jesus the Savior. Presumably one cannot believe oneself to belong to Jesus if He is dead and 
gone (cf. 1 Cor. 15). Neither can one believe that one has been saved by Christ if one does not understand there to be any "problem" from which to be saved. But it is also clear that such a self-understanding is consistent with a variety of opinions in matters of theological controversy such as Trinity, Incarnation, and Atonement. This is not to say that there is not a fact of the matter about what the Trinity is or how Christ accomplishes the Atonement, but only that being a Christian does not essentially require or consist in knowing that fact of the matter or assenting to some well-defined doctrinal statement. What is essential to Christian faith is not so much its "propositional content," but rather its object and its mode of intending: Christian faith intends the person of Christ as Savior.

Such a self-understanding arises as a result of the proclamation of the Gospel. Christ claims people as His own, and they come to know about it through the preaching of the Gospel. As Paul wrote: "Faith comes from what is heard, and what is heard comes through the word of Christ" (Rom. 11:17). This suggests that the preaching of the Gospel ought to take the form of the communication of an actual, present reality, and not merely a conditional offer. In other words, the Gospel is the unconditional announcement that Christ has accomplished one's salvation and has committed Himself to one in such a way that He will bring one to God (cf. 1 Pet. 3:18). Phillip Cary writes that, in this way, the Gospel is a sacrament, since it communicates Christ to the person who hears it (Cary 2019). How does it communicate Christ? He gives this analogy: "The Gospel is a promise like the wedding vow by which a Bridegroom gives himself to his beloved, but it is also the story of Christ in which that promise is found" (Cary 2019, 175). Just a bridegroom hands himself over to his bride through a promise, so also Christ is handed over to the believer through the Gospel. And the Gospel message is something like this this: Christ has died to make atonement for your sins and has dedicated Himself to the project of bringing you to eternal life with God in peace and salvation. As far as He is concerned, you already belong to Him, so that you have nothing to fear from Him. Only, for your sake, so that you do not bring about your own demise, do not disobey Him or run away from Him (cf. Col. 1:21-23). One becomes a Christian when one is told this and believes it. Note also: because this has been the message of Christianity in every age, it is easy to see how the saving truth can have been preserved apart from an infallible Magisterium and even while various doctrinal falsehoods were propagated and required by Church authorities.

The alternative to an unconditional formulation of the Gospel is a conditional one: "If you repent, if you have faith, if you do $x, y$, or $z$, then all of Christ's benefits will be yours." But the problem with such a formulation is that it has the tendency to invite an introspective attitude in which one is constantly questioning oneself, unsure of whether or not one has truly repented, or has the true faith, or has been validly baptized, or belongs to the True Church, or whatever. It can inspire a kind of "salvation-anxiety" precisely because (i) one has been told that one is in deep trouble, and yet (ii) Christ, as He has been presented, does not straightforwardly assure one of His help. Indeed, one is told that only Christ can help, and yet it is clear that, in an important sense, one is stuck having to save oneself, because one is put in the position of constantly interrogating oneself and attempting to discern whether one fulfills the conditions of salvation. One cannot remain in this "salvation-anxiety" forever. One must either despair of salvation altogether, or else eventually realize that one has no 
other option except simply to trust in Christ's goodness. But it would also seem desirable not to bring up these problems in the first place. Thus, if one is sympathetic to the doctrine of ecclesiological sola fide, according to which being a Christian is a matter of understanding oneself to Christ, one's Savior, then it would seem more consistent to opt for an unconditional interpretation of the Gospel over a conditional one.

It might also seem obvious that an interpretation of the Gospel as unconditional promise fits better with an understanding of election as universal. Recall that, according to ecclesiological solus Christus, Christ's attitude towards His Church, which He claims as His own, is one of pure salvific intent. If Christ does not claim everyone as His own, then it would seem that one would have no basis for preaching an unconditional Gospel to all persons! One could not be sure that Christ's intent toward those to whom one preaches is in fact salvific. On the other hand, if election is not universal, then the argument can be given that one can hardly be confident in one's own election. Phillip Cary stresses this point in some detail (Cary 2019, 245-56). In virtue of what can a person know that he or she is elect? He or she will plainly struggle at times; he or she will plainly have moments of doubt or trouble; he or she will plainly pale in comparison to others of differing convictions whose spiritual qualities are more impressive; and so on. There is always a reason to think one is not elect, if one knows where to look for it. Neither can one appeal to some kind of "inner sense" of one's own election. Such an "inner sense" could at best consist in a form of "propositional perception." It has already been argued that one cannot perceive the truth of a proposition in the absence of its referent. And what is the referent of the proposition that one is elect? It is the fact that God chooses a person. But if this fact is not made public, e.g. through the death of Christ on behalf of all persons, then it is inaccessible and thus one cannot know one's election. And if one cannot know one's election, one cannot confidently take oneself to belong to Christ, as ecclesiological sola fide requires. So it is better to think of election as universal.

Beyond the universal understanding of election, ecclesiological sola fide would also seem to require a highly objective and actualized understanding of the Atonement. The work of Christ is complete, a fait accompli, an accomplishment, before it is preached about and believed in. Only in this way can one avoid the introspection and self-interrogation which would inevitably arise if one were to posit some condition to be fulfilled on the part of the believer. Is Christ's work only effective for the truly faithful? For the validly baptized? For those who receive a valid Eucharist? For those who are not in a state of mortal sin? Every time a condition is placed on the efficacy of the work of Christ that has to do with the believer, a number of questions are raised, and one is thrown back into the endless dialectic and debates of Christian theology. These matters are so hotly contested because the participants in the debate are operating on the basis of a "doctrinal" conception of the Church. In order to belong to the Church (and, implicitly, fully and surely to benefit from Christ's work), one must believe precisely the right things. Fallibilist ecclesiology seeks to avoid these problems. It emphasizes, as T.F. Torrance wrote, "the objectivity of grace, not ... faith itself, for in faith we look to Christ and away from ourselves and our own believing" $(1996,58)$. For that reason, it would seem better to opt for a highly objective and actualized understanding of the Atonement. The work of Christ is complete and 
finished. Nothing more needs to be done. What is left is merely for human beings to enjoy its benefits and thank God for it. ${ }^{3}$

\section{Fallibilist ecclesiology summarized}

This, then, is the basic content of a fallibilist ecclesiology. The objective being of the Church consists in the fact that Christ claims some number of persons as His own. Although the system does not require this, many theological problems are avoided if one thinks that Christ claims everyone as His own without exception. The subjective fulfillment of this in the life of a Christian consists in the persistent and abiding selfunderstanding that one belongs "body and soul, in life and in death" to Christ one's Savior. This self-understanding would seem to fit best with a doctrine of universal atonement, an interpretation of the Gospel as an unconditional proclamation and promise, and a highly objective and actualized doctrine of the Atonement. This is what it means to be the Church and to be a Christian. It is compatible with a vast diversity of theological and doctrinal convictions. One need not believe anything in particular, say about Atonement or Trinity. Everything else one might say is built on top of this.

\section{In Conclusion: Theology Without Anathemas}

The discussion until this point has been long. It has been argued that, if one grants the phenomenological conception of knowledge as "seeing" something given to consciousness, then infallible knowledge is matters of Christian theology is not presently possible. Both the Protestant doctrine of claritas scripturae and the Roman Catholic understanding of the infallibility of the Magisterium have been rejected. In place of a "doctrinal" conception of the Church, a "fallibilist" ecclesiology has been proposed. Belonging to the Church and being a Christian is not a matter of "believing the right things." To be the Church is to have been claimed by Christ as His own. To be a Christian is to consider oneself to have belong to Christ. But what is the significance of this proposal?

In the first place, it should be obvious how, if one accepts the proposals of this essay, there is no need for an infallible Magisterium to secure the accessibility of the truth throughout the ages. The one saving truth is this: All people always already are claimed by Christ, because He has died for them and committed Himself to their salvation. Everything else one might say in theology is built upon this. This is something so obvious, that there is no need for an infallible Magisterium to secure its preservation. Consider this analogy. Suppose there is a wide and powerful river next to a village, and anyone can at any time go to the river to drink from it. It would be

\footnotetext{
${ }^{3}$ What room is there in a fallibilist ecclesiology so defined for a sacramental theology? This is a matter to be pursued in later work. But at the very least, one could say that fallibilist ecclesiology would seem to fit better with a notion of the sacraments as symbolic celebrations and reenactments of the alreadyaccomplished salvation of the individual. They do not make the salvific work effective for the individual, since it always already is effective: one always already belongs to Christ.
} 
absurd to suppose that there is need of an infallible guide to direct the villagers toward to the river and to teach them a precise method of drinking from it. In the same way, there is no need of an infallible Magisterium to secure the truth that all belong to Christ, plain as it is in Scripture and in nearly every act of preaching. It is enough simply to have faithful people who can discern this message in Scripture.

Granting that there is no need of infallibility and that the saving truth is an obvious and easily accessible one, indeed a truth about a salvation that is always already a reality, it would seem, in conclusion, that fallibilist ecclesiology makes it possible to do "theology without anathemas." What does this mean? It means that it is possible to pursue the task of Christian theology - the knowledge of God and of all things as they relate to God - collaboratively, cooperatively, even "scientifically," without exclusion, competition, anathematization, judgment, and anxiety. There is no need to draw lines, designating some as "in" and others as "out," some opinions as "orthodox" and others as "heretical." How does it do this? Because, on the one hand, it rejects that infallible theological knowledge is possible. There is no basis for drawing lines in the sand, because one cannot be sure that one is right and the other is wrong. This would make no sense in other contexts where the fallibility of knowledge is obvious (e.g., in commentary on matters of sports or politics). The same attitude should also be taken in theology. But it also does away with anathemas because fallibilist ecclesiology teaches that salvation is already a reality. Christ has already accomplished the salvation of all participants in the theological controversies of the present day. Those on both sides of a divisive issue already belong to Him. Therefore, they are not fighting for their souls, nor for the souls of any others, in the disputes in which they participate. They can begin to think about what they are doing in a different way: for example, as a collaborative effort better to understand the mysteries of the Christ to whom they both belong as a result of the intervention of His love for them both.

Does it follow from this that all churches must therefore be one? On the one hand, the proposal of fallibilist ecclesiology would seem to entail that "the Church," the true Church, is in fact one and always has been. It is simply that group of persons whom Christ claims as His own, which is everyone. Thus, the Church is always and has always been one. On the other hand, the plurality and distinction among churches can only arise among those who are Christians, that is, who understand themselves to belong to Christ their Savior, and yet have differences of opinion of such a nature as to lead to visible disunity and division. Fallibilist ecclesiology is compatible in principle with the reasonable "separation" of churches on the basis of differences of opinion. It would simply emphasize that the division is between two parts of the Church which, for whatever reason, determine that they cannot live together in peace given their differences. But it would adamantly reject that the division was a matter of the true Church being revealed and the false church being demasked or cut out. Being the Church is being claimed by Christ, and being a Christian is understanding oneself to have been claimed by Christ - not believing something or other in particular.

The rejection of infallibility in theology thus need not be a disaster. To the contrary, it can become the start of a different way of doing theology. One no longer thinks of one's competitors or rivals as threatening the truth, neither does one allow 
the lucidity and rationality of one's theologizing to be affected by a salvation-anxiety that makes it a matter of life and death that one gets all the right answers. Theology can instead be understood as the collaborative and cooperative effort of those who know themselves to belong to Christ to understand better and deeper the one who loved them and gave His life for them in order to bring them to God.

\section{References}

Bierma, Lyle D. 2016. The Theology of the Heidelberg Catechism: A Reformation Synthesis. Westminster John Knox Press.

Callahan, James Patrick. 1996. "Claritas Scripturae: The Role of Perspicuity in Protestant Hermeneutics." Journal of the Evangelical Theological Society 39(3): 353-372.

. 2001. The Clarity of Scripture: History, Theology and Contemporary Literary Studies. Wipf and Stock.

Calvin, John. 2006. Institutes of the Christian Religion. Edited by John T. McNeill. Translated by Ford Lewis Battles. 2 volumes. Westminster John Knox Press.

Caputo, John D. 2018. Hermeneutics: Facts and Interpretation in the Age of Information. Pelican Books.

Cary, Phillip. 2019. The Meaning of Protestant Theology: Luther, Augustine, and the Gospel that Gives Us Christ. Baker Academic.

Diller, Kevin. 2014. Theology's Epistemological Dilemma: How Karl Barth and Alvin Plantinga Provide a Unified Response. IVP Academic.

Dulles, Avery Cardinal. 2017. Magisterium: Teacher and Guardian of the Faith. Sapientia Press.

Frege, Gottlob. 1948. "Sense and Reference." The Philosophical Review 57(3): 209230.

Gschwandtner, Christina M. 2010. "Can We Hear the Voice of God? Michel Henry and the Words of Christ." In Words of Life: New Theological Turns in French Phenomenology, edited by Bruce Ellis Benson and Norma Wirzba. Fordham University Press.

Heidegger, Martin. 1985. History of the Concept of Time. Indiana University Press. 
Henry, Michel. 2002. I Am the Truth: Toward a Philosophy of Christianity. Translated by Susan Emanuel. Stanford University Press.

. 2008. Material Phenomenology. Translated by Scott Davidson. Fordham University Press.

. 2012a. Barbarism. Translated by Scott Davidson. Continuum.

. 2012b. Words of Christ. Translated by Christina M. Gschwandtner. Eerdmans.

Hildebrand, Dietrich von. 1973. What is Philosophy? Routledge.

Hopp, Walter. 2020. Phenomenology: A Contemporary Introduction. Routledge.

Husserl, Edmund. 1969. Formal and Transcendental Logic. Translated by Dorion Cairns. Martinus Nijhoff.

. 1973. Experience and Judgment: Investigations in a Genealogy of Logic. Translated by Ludwig Landgrebe. Northwestern University Press.

Kärkkäinen, Veli-Matti. 2013. Christ and Reconciliation. Eerdmans.

Marion, Jean-Luc. 2013. Givenness and Hermeneutics. Translated by Jean-Pierre Lafouge. Marquette University Press.

2017. “'They Recognized Him and He Became Invisible to Them."” In Believing in Order to See: On the Rationality of Revelation and the Irrationality of Some Believers. Translated by Christina M. Gschwantdner. Fordham University Press.

Middleton, J. Richard. 2014. A New Heaven and a New Earth: Reclaiming Biblical Eschatology. Baker Academic.

Nemes, Steven. 2017. "On the Priority of Tradition: An Exercise in Analytic Theology." Open Theology 3: 274-292.

. 2019. "Claritas Scripturae, Theological Epistemology, and the Phenomenology of Christian Faith." Journal of Analytic Theology 7: 199-218.

Pannenberg, Wolfhart. 1991. Systematic Theology. Volume 1. Translated by Geoffrey W. Bromiley. Eerdmans.

Ratzinger, Joseph Cardinal. 1988. Eschatology: Death and Eternal Life. Translated by Michael Waldstein. Catholic University of America Press. 
1995. The Nature and Mission of Theology: Essays to Orient Theology in Today's Debates. Translated by Adrian Walker. Ignatius Press.

Sokolowski, Robert. 2000. Introduction to Phenomenology. Cambridge University Press. 2008. Phenomenology of the Human Person. Cambridge University Press.

Sullivan, Francis A. 1983. Magisterium: Teaching Authority in the Catholic Church. Wipf and Stock Publishers.

Thompson, Mark D. 2006. A Clear and Present Word: The Clarity of Scripture. InterVarsity Press.

Torrance, Thomas F. 1996. Scottish Theology: From John Knox to John McLeod Campbell. T\&T Clark, International.

. 2008. Incarnation: The Person and Life of Christ. Edited by Robert T. Walker. IVP Academic.

Vanhoozer, Kevin J. 2016. Biblical Authority after Babel: Retrieving the Solas in the Spirit of Mere Protestant Christianity. Brazos Press.

Zahavi, Dan. 2003. Husserl's Legacy. Stanford University Press. . 2016. Phenomenology: The Basics. Routledge. 